\title{
A NEW SPECIES OF CUCURBITA FROM ECUADOR
}

\author{
by Hugh C. Cutler and Thomas W. WhitakeR ${ }^{1}$ \\ Missouri Botanical Garden, St. Louis and U. S. Department of Agriculture, \\ La Jolla, California
}

\begin{abstract}
A new species of Cucurbita from South America is described. This species, Cucurbita ecuadorensis, is the first wild species of Cucurbita described from northwestern South America. Cucurbita ecuadorensis has been excavated from pre-ceramic, pre-maize levels in Coastal Peru. It appears to be more closely related to the South American C. maxima and $C$. andreana than to other species in the genus.
\end{abstract}

Recent interest in the solitary bees of the genera Peponapis Robertson and Xenoglossa Smith stimulated an intensive search for species of Cucurbita and the bees associated with each species (Hurd \& Linsley, 1964, 1966, 1967). On a collecting trip for solitary bees, Dr. and Mrs. A. E. Michelbacher were in Ecuador from January 27 to February 16, 1965. They made three collections of a large, wild gourd. Through the courtesy of the Michelbachers, seeds from these collections were grown in experimental gardens and greenhouses at Tucson, Arizona, and La Jolla, California. These collections belong to an undescribed species of Cucurbita.

Cucurbita ecuadorensis Cutler \& Whitaker, sp. nov.-Fig. 1-3.

Plants scandens ad $10 \mathrm{~m}$ fortasse plus alta, spicula et trichomata diffusa, interdum ad nodos radicans, cirrhi crassi, saepe tripartiti et plerumque circinati; folia plerumque $12-32 \mathrm{~cm}$ lata, lato-ovato ad reniforma, lamina opaco-viridis, plerumque superficie pallido-viridis, basi lato-cordata, quinquelobata, lobi laterales saepe vadosiores, lobi basales circiter ad dimidium distantiae versus costam divisi, apice mucronati, supra diffuso-ciliati, subtus pubescentes, margines irregulares, petioli maturi, $8-16 \mathrm{~cm}$ longi, plerumque laminam aequantes, trichomatibus et apiculis ornati; flores solitarii campanulati aurantiaco-fulvi; flores staminati pedicellati, pedicellis brevibus ciliatis, $2-5 \mathrm{~cm}$ longis, corolla $5-8 \mathrm{~cm}$ longa, tubus $3-5 \mathrm{~cm}$ longus, calyx ciliatus, lobi angusti et acuti, $1-2 \mathrm{~cm}$ longi; flores pistillati pedicellati, pedicellis brevibus, ciliatis, $2-5 \mathrm{~cm}$ longis, corolla $5-9 \mathrm{~cm}$ longa, tubus $3.5-5 \mathrm{~cm}$ longus, lobi calycis filiformes, $1 \mathrm{~cm}$ longi, pedunculi graciles, $4-8 \mathrm{~cm}$ longi angulati, apiculati, origine vix turgidi; pepo globosus vel subglobosus, $16 \mathrm{~cm}$ diametro, cremeus ad opaco-viridis, plerumque cremeus et lineis viridibus maculisque ornatus, interdum maturite fulvi, pulpa alba, saepe acris sed magis sapore placenti parata,

\footnotetext{
${ }^{1}$ We are pleased to acknowledge the cooperation of Dr. and Mrs. A. E. Michelbacher and Professor Paul D. Hurd, Jr. of the University of California, Berkeley, for making collections and contributing the materials that made this study possible. The Latin description was prepared by Dr. John D. Dwyer, St. Louis University, the chromosome counts and information on species hybridization were furnished by Dr. W. P. Bemis, University of Arizona, and the electrophoretic analyses by Dr. J. R. Wall, Texas Technological College.
}

ANN. Missouri Bot. Gard. 55(3): 392-396, 1969. 


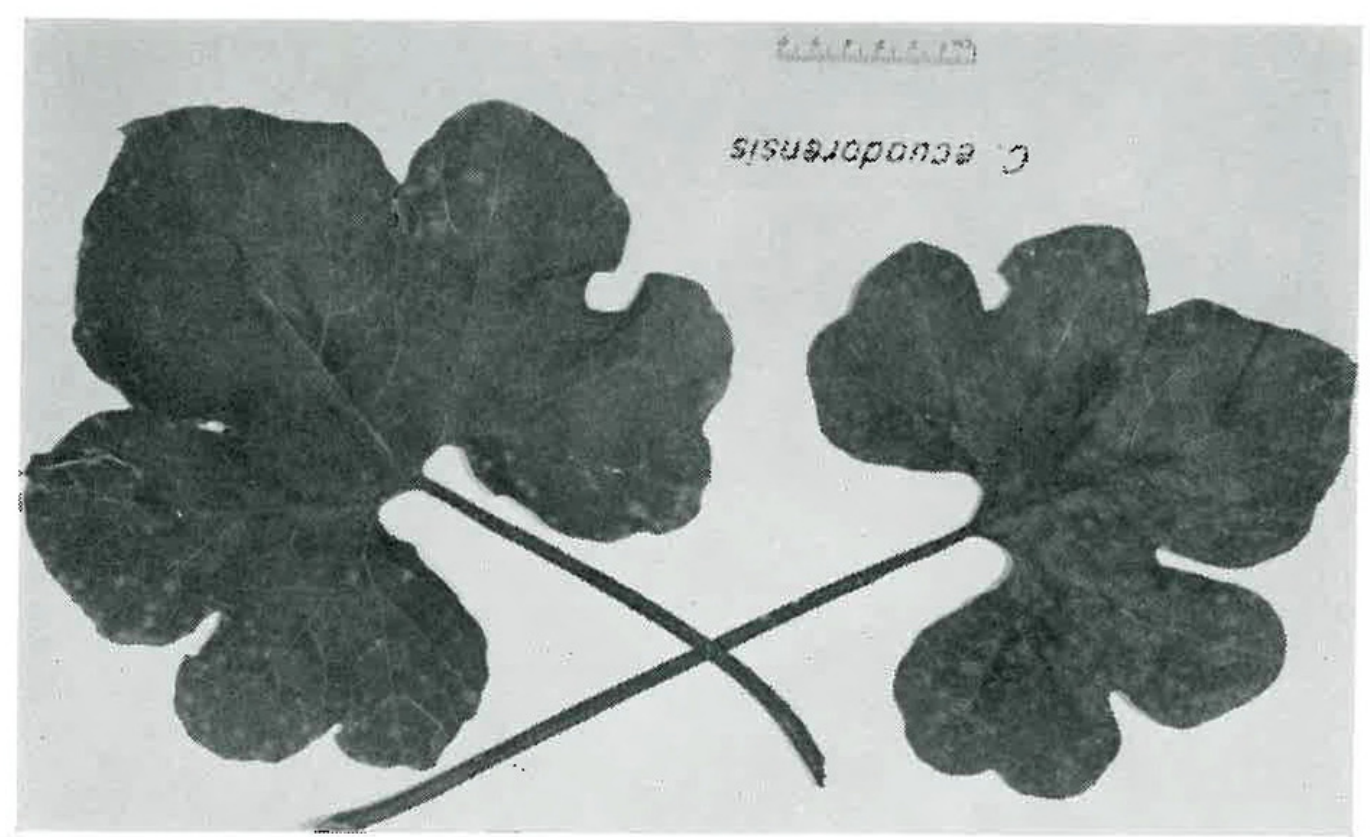

Fig. 1. Typical mature leaves of Cucurbita ecuadorensis grown at La Jolla from seed collection in Guayaquil, Ecuador; note 5-lobed leaves with traces of secondary lobing; $\times 3 / 10$.

loculi 3, semina ovata, $1.1-1.5 \mathrm{~cm}$ longa, $0.7-0.8 \mathrm{~cm}$ lata, corpus album ad brunneolum, margo quam corpore conspicue opacior.

Annual when grown in California and Arizona; vine up to $10 \mathrm{~m}$ or more, often clambering over shrubs; stems striate with scattered spicules and hairs, sometimes rooting at the nodes; tendrils thick, usually tripartite, often coiled on themselves; leaves usually $12-32 \mathrm{~cm}$ wide, broadly ovate to nearly reniform in outline; blade dark green, usually with light green blotches on upper surface, base broadly cordate, deeply 5-lobed, lateral lobes often shallower, basal lobes often divided nearly $1 / 2$ way to mid-vein, tips of lobes mucronate, upper surface with scattered hairs, lower surface pubescent; margins irregular, denticulate at vein ends; petiole $8-16 \mathrm{~cm}$ long when mature, usually as long as blade, with hairs and spicules; flowers solitary, campanulate, orange-yellow; staminate on short, hairy pedicels $2-5$ cm long; corolla 5-8 cm long; tube 3-5 cm long; calyx hairy, lobes narrow and pointed, $1-2 \mathrm{~cm}$ long; pistillate on short, hairy pedicels, $5 \mathrm{~cm}$ long; corolla $5-9 \mathrm{~cm}$ long; tube 3.5-5 cm long; calyx-lobes filiform, $1 \mathrm{~cm}$ long; peduncle slender, $4-8 \mathrm{~cm}$ long, angled, spiculate, slightly enlarged at attachment; pepo to $16 \times 16 \mathrm{~cm}$, creamy to dark green, usually creamy with green lines and spots, sometimes turning yellow at maturity; flesh white, stringy, sometimes bitter, but usually with pleasant cucumber-like flavor; locules 3; seeds ovate, $1.1-1.5 \mathrm{~cm}$ long, 0.7-0.8 cm wide; body white to tan; margin conspicuous, darker than body.

Ecuador: $5 \mathrm{mi} \mathrm{W}$ of Guayaquil; abundant, no bloom; dry gourds of previous year hanging from shrubs, 2 Febr 1965 (holotype MO, isotype US). $19 \mathrm{mi} \mathrm{N}$ of Balzar, ca $60 \mathrm{mi}$ $\mathrm{N}$ of Guayaquil, fruits from previous years hanging from shrubs, 4 Febr 1965 (MO, US). On the river nr Ambuqui, NE of Ibarra, in deep hot valley, alt ca 2,500 ft, 14 Febr 1965 


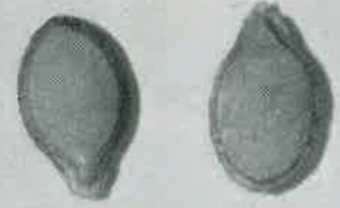

C. ecuadorensis

\section{from Guayaquil}
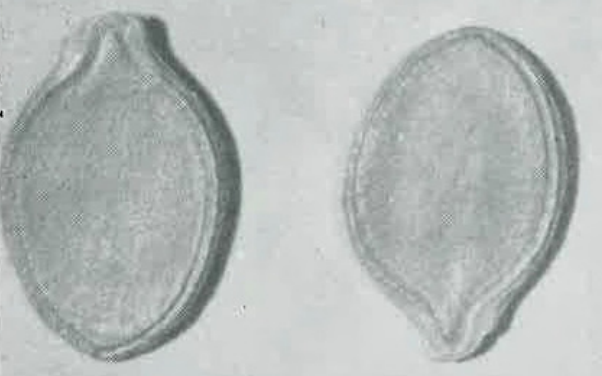

\section{C. ficifolia}

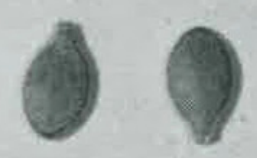

C. andreana
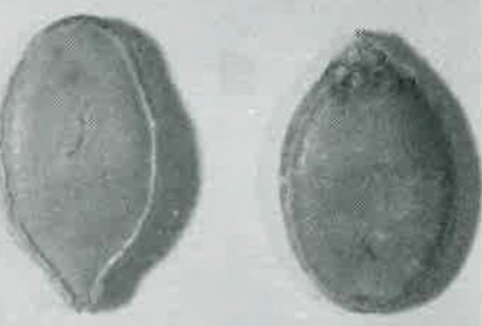

C. maxima

\section{cv. 'Banana'}

Fig. 2. Seeds of Cucurbita ecuadorensis compared with those of celosely related species: C. andreanna, C. maxima \& C. ficifolia; $\times 11 \frac{1}{2}$.

(MO). Nr Ambuqui, hway 1, 14 Febr 1965 (MO). $10 \mathrm{mi} \mathrm{N}$ of Guayaquil, 15 Febr 1965. All by Michelbacher \& Michelbacher s.n.

Peru: Site PV45-136 on Bay of Ventanilla, cut 1, level 7, and cut 1A, level 6. Estimated to be from 3000 B.C., Edward P. Lanning s.n. (MO).

California: La Jolla, grown from seeds collected by the Michelbachers at the type locality (MO, US). La Jolla, grown from seeds collected by the Michelbachers nr Ambuqui; Highway 1, (MO, US). Both by Whitaker s.n.

The species differs from the weedy Cucurbita andreana Naud. in having large, deeply lobed leaves, and a large, globular non-bitter fruit. The only other preColumbian species of Cucurbita from South America are the cultivated ones, C. ficifolia Bouche, C. moschata Duchesne ex Poir. and C. maxima Duchesne. Cucurbita ecuadorensis differs from wild Central American and North American species by the large leaves and fruit, by the virtual absence of bitter taste in the flesh of the fruit, and by the prominent seed margins. The margins are slightly darker than the cream color or light tan seed body.

Rinds, seeds and peduncles of a species of Cucurbita, similar to C. ecuadorensis, 


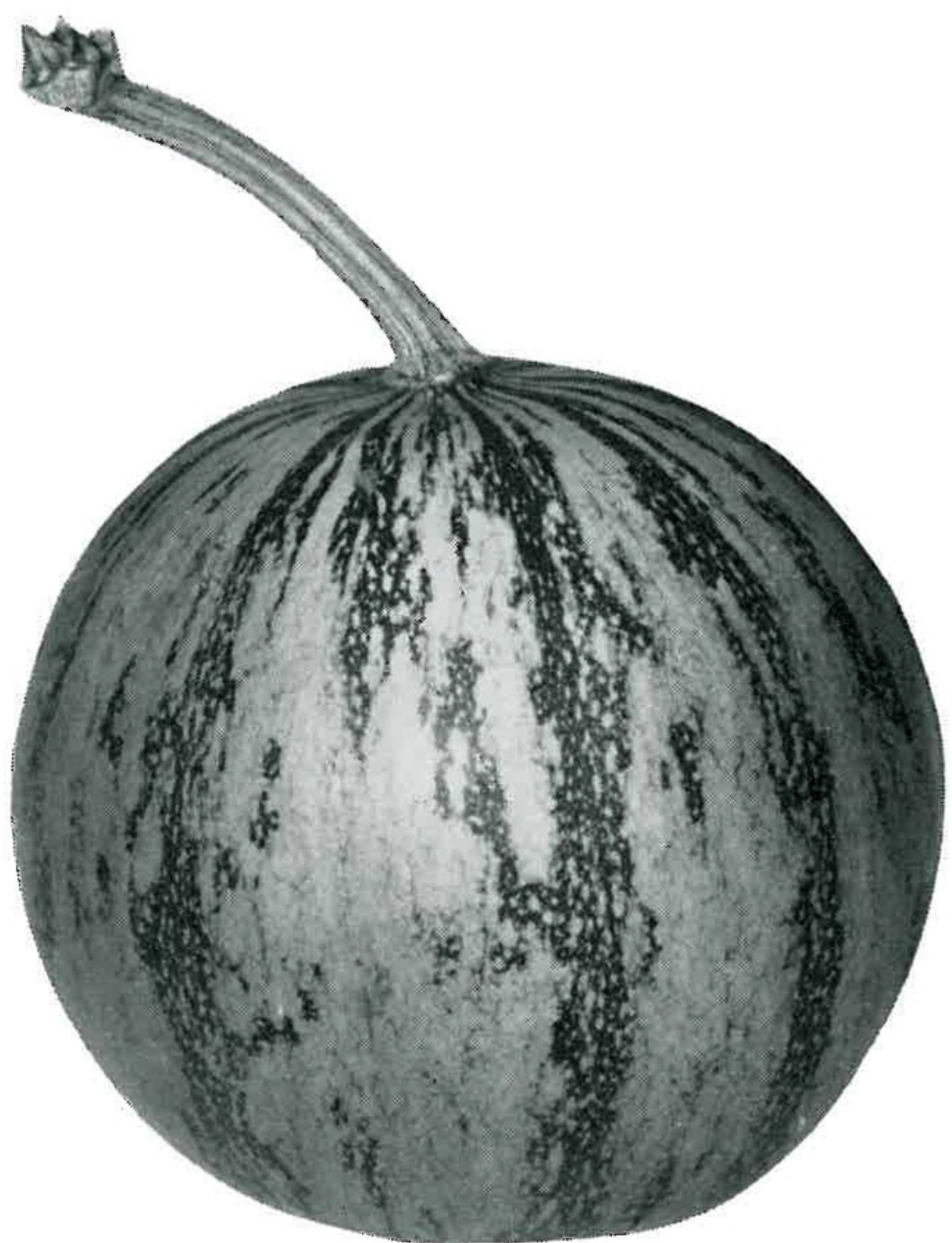

Fig. 3. Fruit of Cucurbita ecuadorensis; $\times 3 / 5$.

have been excavated by Lanning (1967) from pre-Columbian pre-ceramic and pre-maize sites in coastal Peru. He lists these specimens as C. andreana and as a wild cucurbit.

Cucurbita ecuadorensis has 20 pairs of chromosomes, the same as other species of Cucurbita. It hybridizes readily with C. maxima (Whitaker, Bemis \& Wall, unpublished data). Fertility decreases to about $50 \%$ in the $\mathrm{F}_{1}$ plants, but $\mathrm{F}_{2}$ progenies, and backcrosses to either parent can be obtained. Fertility is greatly decreased in most individuals in the $\mathrm{F}_{2}$ and backcross progenies. Some individuals in these progenies are characterized by complete sterility of the staminate or pistillate flowers. Also, various patterns of chlorophyll deficiencies of both leaves and stems occur.

Hybrids between Cucurbita ecuadorensis and the following species have been made and $\mathrm{F}_{1}$ plants grown: C. moschata, C. lundelliana Bailey, and C. okeechobeensis Bailey. The fertility of these hybrids has not yet been determined. Cucurbita ecuadorensis was included in a numerical taxonomic study of Cucurbita (Rhodes et al., 1968). The results indicate it was not closely associated with other 


\section{$2 \mathrm{BHL}$ Biodiversity Heritage Library}

Cutler, Hugh C. and Whitaker, Thomas W. 1968. "A New Species of Cucurbita from Ecuador." Annals of the Missouri Botanical Garden 55, 392-396.

https://doi.org/10.2307/2395132.

View This Item Online: https://www.biodiversitylibrary.org/item/65869

DOI: https://doi.org/10.2307/2395132

Permalink: https://www.biodiversitylibrary.org/partpdf/9263

\section{Holding Institution}

Missouri Botanical Garden, Peter H. Raven Library

\section{Sponsored by}

Missouri Botanical Garden

\section{Copyright \& Reuse}

Copyright Status: In copyright. Digitized with the permission of the rights holder.

License: http://creativecommons.org/licenses/by-nc-sa/3.0/

Rights: https://biodiversitylibrary.org/permissions

This document was created from content at the Biodiversity Heritage Library, the world's largest open access digital library for biodiversity literature and archives. Visit BHL at https://www.biodiversitylibrary.org. 